\title{
Dietary protein hydrolysate and trypsin inhibitor effects on digestive capacities and performances during early-stages of spotted wolffish: Suggested mechanisms
}

\author{
A. Savoie $^{a}$, N.R. Le François ${ }^{a, b, *}$, S.G. Lamarre ${ }^{a, c}$, P.U. Blier ${ }^{a}$, L. Beaulieu ${ }^{a, d}$ and C. Cahu ${ }^{e}$ \\ a Département de biologie, Université du Québec à Rimouski, Rimouski, QC, Canada G5L 3A1 \\ ${ }^{\mathrm{b}}$ Biodôme de Montréal, 4777, Ave Pierre-De Coubertin, Montréal, QC H1V 1B3 \\ ${ }^{c}$ Memorial University of Newfoundland, St-John, NL, A1C 5S7 \\ ${ }^{d}$ Institute of Nutraceuticals and Functional Food (INAF), Université Laval, Québec, Québec, G1V 0A6, Canada \\ e Ifremer, Nutrition, Aquaculture \& Genomic Research Unit, F-29280 Plouzane, France \\ *: Corresponding author : N.R. Le François, Tel.: + 1514868 3072., \\ email address : NLe Francois@ville.montreal.qc.ca , Nathalie Le-Francois@uqar.qc.ca
}

\begin{abstract}
:
Growth rate is dependent upon adequate provision of amino acids especially in newly-hatched fish which experience very high growth rate. The replacement of a fraction of protein content by partially hydrolyzed (pre-digested) proteins was carried out and the digestive capacities and performances of larval/juvenile spotted wolffish (Anarhichas minor) were measured. The goal of this study was to verify whether the scope for growth is principally dictated by the proteolytic capacity of the digestive system by examining the effect of protein hydrolysates $(\mathrm{PH})$ and trypsin inhibitor dietary inclusion on protein digestion/assimilation capacities, growth and survival. Four experimental diets were examined: $\mathrm{C}$ (control) I (supplemented with $750 \mathrm{mg} / \mathrm{kg}$ soybean trypsin inhibitor (SBTI)) H (supplemented with $20 \%$ $\mathrm{PH}$ ) and $\mathrm{HI}$ (supplemented with 20\% PH and $750 \mathrm{mg} / \mathrm{kg} \mathrm{SBTI}$. Protein hydrolysate supplementation gave significantly higher body mass than control at day 15 post-hatching. Unexpectedly, at day 30 and 60, fish administered diet $\mathrm{HI}$ (containing trypsin inhibitor) were heavier than the other groups. Suggested mechanisms are presented and discussed. The main conclusions of this study are that wolffish larval stage lasts roughly 15 days and that juvenile growth is linked to proteolytic capacity, but also very likely to absorption capacity of peptides and amino acids.
\end{abstract}

Keywords : Spotted wolffish; Anarhichas minor; Early-stages; Trypsin inhibitor; Protein hydrolysate; Digestive capacity; SBTI 


\section{Keywords:...}

\section{Introduction}

Along with the dynamic and complex processes of organ differentiation and morphogenesis, the newly-hatched fish experience the highest growth rate that they will ever achieve in their entire lifetime (Gisbert and Williot, 2002; Sala et al. 2005). Growth rate is mainly a function of protein synthesis and deposition and is the net income of behavioural and physiological processes that begins with food intake (Lamarre et al. 2010). Accordingly, and especially during the early stages, rapid growth is reliant upon adequate provision of amino acids (aa). It has been suggested that protein digestion and amino acids assimilation could set a limit on growth rate in juvenile fish (Blier et al. 1997). Not surprisingly, trypsin activity, a keyenzyme of protein digestion, is correlated to growth rate and survival in various fish species (Sharma and Chakrabarti, 1999; Lemieux et al., 1999) including wolffishes (Lamarre et al., 2004; 2007). Growth performances are thus clearly limited by the efficiency of the digestive system to provide amino acids for protein synthesis and energy production.

Protein is usually the main component of fish feed and fish rely on proteases for their digestion. Many studies have shown that the replacement of a fraction of protein content by partially hydrolyzed (pre-digested) proteins could enhance performances of larval fish. If digestive capacity is a limiting factor at first-feeding, offering more digestible dietary proteins should improve both growth and survival, since proteins are absorbed mainly as smaller peptides or single amino acids (Silk et al., 1985; Rust, 1995; Ronnestad et al., 2001;

Kotzamanis et al. 2007).

Positive effects of dietary protein hydrolysate supplementation on growth and survival have only been reported on larval stages of fish when the digestive system is actively developping. Medium level of inclusion of protein hydrolysate enhanced survival and/or growth in larval stages of seabass (Dicentrarchus labrax, Zambonino Infante et al. 1997; Cahu et al. 1999), common carp (Cyprinus carpio, Carvalho et al., 1997) and barramundi (Lates calcarifer, Nankervis and Southgate, 2009). On the other hand, no or negative effects of PH have been reported on juvenile fish such as rainbow trout (Oncorhynchus mykiss, Stone et al., 1989) and juvenile turbot (Scophthalmus maximus, Oliva-Teles et al., 1999). Most marine fish larvae hatch with a rudimentary digestive system and undergo a metamorphosis prior to the onset of exogenous feeding. Newly-hatched larvae generally display low activity of digestive enzymes 
(Kolkovski, 2001) and many species do not even present a functional stomach (Govoni et al., 1986). On the other hand, spotted wolfish (Anarhichas minor, Olafsen) is a particular case because it displays external morphology and internal organs that are not typical of larval fish (Falk-Petersen and Hansen, 2001). This species hatches well developed at a relatively large size (20-24 mm), displays a fully functional digestive system, fairly high trypsin activity (Desrosiers et al., 2008; Savoie et al., 2008) and readily accept exogenous food (Falk-Petersen \& Hansen 2001; Lamarre et al. 2004; 2007). Accordingly, the distinction betwen larval and juvenile stages is rather arbitrary in fish (Paine and Balon 1984; Flegler-Balon 1989, Copp and Kovac, 1996) and wolffish hatch with very few remaining larval characteristics (FalkPetersen and Hansen, 2001). In this experiment, fish up to 15 days post-hatching (DPH) were considered as newly-hatched fish and after $30 \mathrm{DPH}$ as true juveniles. This bottow-dwelling marine fish has been identified as a threatened species in Canadian coastal waters (Kulka et al., 2007), a species of concern in the USA (AWBRT, 2009) and is the object of directed research and development efforts that include aquaculture interests as well as population conservation concerns (Le François et al. 2002; 2010). Hence, a better understanding of the early-life processes governing survival and growth of spotted wolffish is warranted.

Trypsin (TRYP) and chymotrypsin (CHY) are proteolytic enzymes secreted by the pancreas and liberated in the digestive tract as inactive precursors, respectively trypsinogen and chymotrypsinogen, activated once in the digestive tract. They are both endopeptidases that break peptide bonds of specific non-terminal amino acids within the protein. Aspartate amino transferase (AST) is indicative of the capacity to oxidize amino acids for energy production or of transamination for protein synthesis.

The goal of this study was to verify whether the scope for growth is dictated by the proteolytic capacity by examining the effect of protein hydrolysates ( $\mathrm{PH})$ and trypsin inhibitor dietary inclusion on protein digestion/assimilation capacities, growth and survival. The inhibitor used in this study was soybean trypsin inhibitor (SBTI), which inhibits trypsin and to a lesser extent, chymotrypsin. We suggest that the capacity to digest proteins sets a limit to the expression of growth potential in first-feeding wolfish. The first prediction that we formulate to test this hypothesis is that growth will be enhanced by the presence of $\mathrm{PH}$ in the feed but hindered by the addition of a trypsin inhibitor. The second prediction is that the decrease in growth rate induced by the inhibitor of trypsin will be counterbalanced by the inclusion of $\mathrm{PH}$. 
106 The study was carried out at the facilities of the Centre Aquacole Marin de Grande-Rivière,

107 Québec, Canada. Fertilized spotted wolffish eggs originating from captive female wild

108 broodstock were incubated as described in Savoie et al. (2006). Hatching began on February

$10928^{\text {th }} 2007$ and entire hatching was stimulated on March $13^{\text {th }}$ by gentle mixing of the eggs.

110 Day 0 of the experiment was considered to be March $14^{\text {th }}$. Newly hatched fish (mean weight

$1110.103 \pm 0.01 \mathrm{~g}$ and mean length $24.5 \pm 1.4 \mathrm{~mm}$ ) were randomly placed in each of the 12 low-

112 level $(2 \mathrm{~cm})$ rearing units containing 1.5 litres with a water supply of 1 litre/minute and

113 individual aeration ( $\mathrm{n}=50$ per unit). Feeding of all experimental groups was initiated on

114 March $14^{\text {th }}$. Mean salinity during the sixty days of the experiment was of $31.3 \pm 0.1$, oxygen

115 saturation was always above 85\% (mean $86.8 \pm 2.2 \%$ ) and a 12/12-h light/dark cycle was

116 adopted. Once a day, mortality was recorded, dead fish were removed and rearing units

117 carefully cleaned.

Nutrition

120 The different treatments (diets) were randomly assigned to twelve rearing units (4 diets in

121 triplicate). Fish were fed by hand each hour from 8am to 5pm for the entire experimental

122 period. As suggested by Savoie et al. (2006), no live prey was distributed to avoid possible

123 interference with negative or positive effects of experimental diets on survival rates. The

124 composition of the four diets and processing details (previously described in Savoie et al.

125 2006) are provided in Table 1. The compound diets were formulated and processed at

126 Ifremer, Centre de Brest (France). It was formulated in order to be isonitrogenous. The four

127 experimental diets contained exactly the same ingredients except for hydrolysates and SBTI

128 content. In the diets " $\mathrm{C}$ " and "I", the protein fraction was fish meal. In the diets " $\mathrm{H}$ " and

129 "HI”, the fish meal was replaced by $20 \%$ of PH. Two pellet sizes were used: $400-800$ and

$130 \quad 800-1200 \mu \mathrm{m}$ according to the fish length and according to the feeding tables adopted in

131 Savoie et al. (2006).

132

\section{Sampling}

134 Twenty-five fish were sampled at day 0 and four fish per tank were sampled at day 15, 30 and

13560 (total: 205 fish). Fish were fasted for 18 hours before sampling. Individual weight (g) and

136 length $(\mathrm{cm})$ were noted and the fish were quickly frozen at $-80^{\circ} \mathrm{C}$ until analysis. A 
supplementary 11 fish were weighed $(\mathrm{g})$ and measured $(\mathrm{mm})$ at each sampling date in order to

138 evaluate growth and calculate productivity of the different experimental groups. Productivity

139 (total biomass produced/tank) was calculated as follow: mean final fish weight $\mathrm{X}$ remaining

140 individuals in a tank (Lopes et al., 2001).

142 Table 1. Composition of the experimental diets for spotted wolffish

\begin{tabular}{|c|c|c|c|c|}
\hline Ingredients $^{1}$ (in \%) & $\mathbf{C}$ & $\mathbf{I}$ & $\mathbf{H}$ & HI \\
\hline Fish meal & 74 & 74 & 54 & 54 \\
\hline HPC 90 & - & - & 20 & 20 \\
\hline Precooked Potatoe starch & 5 & 5 & 5 & 5 \\
\hline Cod liver oil & 3 & 3 & 3 & 3 \\
\hline Soy lecithin & 5 & 5 & 5 & 5 \\
\hline Vitamin Mixture $^{2}$ & 8 & 8 & 8 & 8 \\
\hline Mineral Mixture $^{3}$ & 4 & 4 & 4 & 4 \\
\hline Betaine & 1 & 1 & 1 & 1 \\
\hline SBTI & & 750 mg/kg & & $750 \mathrm{mg} / \mathrm{kg}$ \\
\hline
\end{tabular}

143 1Dietary ingredients were commercially obtained. Fish meal, and cod liver oil were from

144 La Lorientaise (Lorient, France). The soy lecithin was from Ets Louis François (St Maur

145 des Fossés, France). The potato precooked starch (Nutralys) was from Roquette (Lille,

146 France). HPC 90 was from Ocean NutraSciences (Matane, Québec, Canada), SBTI

147 (Trypsin soybean inhibitor) was from Sigma (T-9128).

148 2Per kg of vitamin mix: retinyl acetate $1 \mathrm{~g}$; cholecalciferol $2.5 \mathrm{mg}$; all-rac- $\alpha$-tocopherol

149 acetate $10 \mathrm{~g}$; menadione $1 \mathrm{~g}$; thiamin $1 \mathrm{~g}$; riboflavine $0.4 \mathrm{~g}$; D- calcium pantothenate 2 g;

150 pyridoxine $\mathrm{HCl} 0.3$ g; cyanocobalamin 1 g; niacin 1 g; choline chloride 200 g; ascorbic

151 acid $20 \mathrm{~g}$; folic acid $0.1 \mathrm{~g}$; biotine $1 \mathrm{~g}$; meso-inositol $30 \mathrm{~g}$.

152 3Per kg of mineral mix: KCl 90 g; KI 40 mg; $\mathrm{CaHPO}_{4} 2 \mathrm{H}_{2} \mathrm{O} 500 \mathrm{~g} ; \mathrm{NaCl} 40$ g;

$153 \mathrm{CuSO}_{4} \cdot 5 \mathrm{H}_{2} \mathrm{O} 3 \mathrm{~g} ; \mathrm{ZnSO}_{4} \cdot 7 \mathrm{H}_{2} \mathrm{O} 4 \mathrm{~g} ; \mathrm{CoSO}_{4} \cdot 7 \mathrm{H}_{2} \mathrm{O} 20$ mg; $\mathrm{FeSO}_{4} \cdot 7 \mathrm{H}_{2} \mathrm{O} 20$ g; $\mathrm{MnSO}_{4} \cdot \mathrm{H}_{2} \mathrm{O} 3$

154 g; $\mathrm{CaCO}_{3} 215$ g; $\mathrm{MgSO}_{4} 7 \mathrm{H}_{2} \mathrm{O} 124 \mathrm{~g} ; \mathrm{NaF} 1 \mathrm{~g}$. 
Enzymatic assays

Whole individuals were thawed on ice and homogenised in 9 volumes of Tris-HCl buffer (100mM, pH 7.5) using a Ultra Turrax T25 (IKA Labortechnik) electrical homogeniser for three 10-s periods. Between each period, samples were kept on ice for $1 \mathrm{~min}$. Homogenate was centrifuged at $7000 \mathrm{~g}$ for 1 minute prior to the enzymatic assays. The different enzyme activities were measured using a Lambda 11 UV/VIS spectrophotometer equipped with a thermostated cell holder (Perkin Helmer inc.). Conditions for enzyme assays were as follows:

Aspartate aminotransferase (AST, E.C. 2.6.1.1): Aspartate (22mM), phosphate buffer (100mM) pH 7.4 (Schwartz, 1971). Trypsin (TRY, E.C. 3.4.21.4): Benzoyl-L-arginine-pnitroanilide (2.3 mM), Tris-HCl 0.2 M and $\mathrm{CaCl}_{2} 0.04 \mathrm{M}$ buffer, $\mathrm{pH} 8.0$ (Erlanger et al., 1961 Desrosiers et al. 2008, Lemieux and Blier, 2007). Chymotrypsin (CHY, E.C. 3.4.21.1): Succinyl-Ala-Ala-Pro-Phe-p-nitroanilide (2 mM), Tris-HCl $0.1 \mathrm{M}$ and $\mathrm{CaCl}_{2} 0.01 \mathrm{M}$ buffer, pH 7.8 (Delmar et al., 1979). Total protein content of muscle was determined using the bicinchoninic acid method (Smith et al. 1985). Enzyme assays were conducted at $15{ }^{\circ} \mathrm{C}$ and protein analyses were conducted at room temperature $\left(\approx 23^{\circ} \mathrm{C}\right)$. All enzymatic assays were run in duplicate and protein assays in triplicate.

\section{Molecular weight distribution of the protein hydrolysate}

Size exclusion chromatography (SEC). Molecular weight distribution of the HPC90 protein hydrolysate (Ocean NutraScience Inc., Matane (QC), Canada) was determined by gel permeation chromatography (GPC) on a Superdex Peptide HR 10/300 GL column (GE Healthcare, Baie-d’Urfé, QC, Canada) with an exclusion limit of $1 \times 10^{5}$ Da (13 $\mu \mathrm{m}, 10$ x 300$310 \mathrm{~mm}$ ) using a high-pressure liquid chromatography system (HPLC Waters, Mississauga, ON, Canada)(Beaulieu et al., 2009). The system was equipped with a Waters 996 Photo Diode Array detector, a Waters 600 solvent delivery pump and a Waters 717 plus autosampler. The mobile phase (isocratic) consisted of $50 \mathrm{mM}$ sodium phosphate buffer containing $150 \mathrm{mM}$ of $\mathrm{NaCl}$ at $\mathrm{pH}$ 7.0. In accordance with instructions from the supplier, the column was calibrated using peptides of known molecular weight (GE Healthcare, Baied’Urfé, QC, Canada) as reference samples. Ribonuclease A (1mg/ml), aprotinin $(1 \mathrm{mg} / \mathrm{ml})$, vitamin B12 (0.1mg/ml) and cytidine 5'-monophosphate (Sigma, Oakville, ON, Canada) $(0.1 \mathrm{mg} / \mathrm{ml})$ were mixed together for the calibration of the Superdex Peptide HR 10/300 GL column. This yielded a near linear correlation between the retention time and the log of the molecular mass of peptides in the range of 367 to 13700 Da. Millenium ${ }^{32}$ (version 3.2) 
software was used to analyse the chromatographic data. The protein hydrolysate sample (50 $\mu \mathrm{l}, 1 \mathrm{mg} / \mathrm{ml}$ ) prepared in $50 \mathrm{mM}$ sodium phosphate, $150 \mathrm{mM} \mathrm{NaCl}, \mathrm{pH} 7.0$ was eluted at a flow rate of $0.5 \mathrm{ml} / \mathrm{min}$ and monitored at an absorbance of $280 \mathrm{~nm}$.

\section{Statistical analyses}

To detect the potential effect of diet on survival rate, productivity and final weight, an analysis of variance was performed using the general linear model procedure in Systat 10.2 computer software. Survival rates were arcsin transformed. When a significant difference was detected, a Fisher LSD post hoc test was used. To detect possible interaction between the effect of diet and weight on enzymatic activities, analysis of covariance (factors: diet, weight and diet $\times$ weight) was performed using the general linear model procedure. When no effect of weight on enzymatic activity was detected within a group, an analysis of variance with diet as factor was performed. When a significant interaction was detected between diet and weight, a linear regression of weight and enzymatic activity was performed for each diet. Enzymatic activities were log transformed prior to analysis. Treatments were considered significantly different when $\mathrm{P}<0.1$.

\section{Results}

\section{Inhibitory capacity of the formulated diets containing SBTI}

In order to confirm the effectiveness of SBTI when processed in the experimental feed, gross inhibitory activity was initially evaluated and compared for diets C, H, HI and I. Pellets of the four different diets were homogenized with 9 volumes of Tris- $\mathrm{HCl}$ as described above. Trypsin activity was measured according to Erlanger et al. (1961). The concentration of trypsin added to the mixture was $100 \mathrm{U} / \mathrm{ml}$. Assay was repeated 8 times for each diet. The trypsin activity was $1.58 \pm 0.27,1.62 \pm 0.18,0.55 \pm 0.09$ and $0.51 \pm 0.12 \mathrm{U}$ for diet $\mathrm{C}, \mathrm{H}, \mathrm{HI}$ and I respectively. There was no significant difference between $\mathrm{C}$ and $\mathrm{H}$ diet nor between $\mathrm{HI}$ and I but in diets containing SBTI, trypsin activities were reduced by three-fold and significantly lower than in the two other diets. As a result, the inhibitory activity of SBTI in the diets HI and I was confirmed and judged effective.

\section{Analysis of the shrimp protein hydrolysate HPC 90}

The result of the molecular weight analysis (SEC) is presented in Fig. 1. Our estimation revealed that the experimental hydrolysate was composed of $87 \%$ of peptides of around 1900 Da and $13 \%$ of peptides of less than 303 Da. This suggest that the protein hydrolysate was 
224

225

226

227

228

229

230

231

232

233

234

235

236

237

238

239

240

241

242

243

244

245

246

247

248

249

250

251

252

253

254

255

mostly composed of oligopeptides of 10-20 amino acids residues and contained very few free amino acids

\section{Survival, productivity and weight}

At the end of the trial, there was a significant effect of diet on survival and productivity

(Figure 1). Survival was $67.3 \pm 3.5,82.7 \pm 5.7,84.7 \pm 5.9,44.7 \pm 10.9 \%$ and productivity was $38.1 \pm 1.0,46.2 \pm 3.7,58.8 \pm 2.8$ and $24.5 \pm 5.5 \mathrm{~g}$ of fish/tank for group C, H, HI and I respectively. Diet $\mathrm{HI}$ enhanced both productivity and survival compared to the control group ( $p=0.02$ and 0.085 respectively) while diet enhancements of productivity and survival failed to reach significance ( $\mathrm{p}=0.155$ and 0.132 respectively). Productivity and survival were significantly lower in group fed diet I compared to diet HI ( $\mathrm{p}=0.001$ and 0.006 respectively) and diet I was different from control diet for productivity only ( $\mathrm{p}=0.029)$. It is noteworthy that a great variability between replicates, especially in the group I likely precluded differences between groups to be significant.

Fish mass according to diet and time are presented in Fig. 2. At day 15, fish mass was higher in both groups receiving diets containing hydrolysates $(\mathrm{H}$ and $\mathrm{HI}, \mathrm{p}<0.000$ and $\mathrm{p}=0.002$ respectively) and lower for the group I ( $\mathrm{p}=0.021)$ compared to control diet. At day 30 and 60, group $H$ had the same mass as the control but group $H I$ was heavier ( $p=0.001$ and 0.008 for day 30 and 60 respectively). Group I (SBTI without PH) had a lower body mass of all groups after 15 and 30 days but at day 60 achieved a mean mass equivalent to group $\mathrm{C}$ and $\mathrm{H}$ (Fig.3).

\section{Enzymatic activities}

Mean enzymatic activities at day 0 of the experiment were $7.932 \pm 0.325,0.084 \pm 0.008$ and $1.208 \pm 0.034 \mathrm{U} / \mathrm{g}$ fish for AST, CHY and TRY respectively (U per mg protein was calculated revealed the same trends but data are not presented). At day 15, there were some differences between groups but none were significantly different: AST activity was lower when inhibitor was present in the diet (groups HI and I), CHY was higher in group HI and TRY was lower in group I. At day 30, CHY and TRY activities were significantly higher in group HI than in group I. At day 60, only CHY activities were different between groups, CHY activity was higher in group HI than control and group I (Fig. 4). 
257 It was anticipated that $\mathrm{PH}$ would to some extent improve growth rate and survival and that

258 SBTI, would reduce protein digestion capacities through direct trypsin inhibition, and significantly impair those same performance traits. Indeed, diet I (containing SBTI) caused more mortality and slower growth and fish administered diet $\mathrm{H}$ had a higher body mass at day 15 (see Fig. 3). However, diet $\mathrm{H}$ did not led to better performances after 30 and 60 days suggesting sufficient maturation of the digestive system after 15 days to fulfill the digestive requirements in order to maintain a fair growth rate. This is in accordance with many studies which found that hydrolysates are beneficial to fish larvae (Szlaminska et al., 1993; Cahu and Zambonino-Infante, 1995; Carvalho et al., 1997; Zambonino Infante et al., 1997) but do not affect juvenile growth (Cahu and Zambonino-Infante, 2001). According to those results, newly-hatched wolffish up to $15 \mathrm{DPH}$ would benefit from a diet supplemented with PH but not thereafter, when they could be considered as ''true juveniles'”.

In a previous study on the same species, Savoie et al. (2006) obtained some indications that protein hydrolysates could be beneficial to the young spotted wolfish but failed to obtain significant results. The proposed explanation for the absence of a clear benefit following $\mathrm{PH}$ dietary incorporation in this previous experiment, was linked to the insufficient degree of hydrolysis of the commercial protein hydrolysates used (>6500 Da: Asta-Pep ${ }^{\mathrm{TM}}$ ). In comparison, HPC90 ${ }^{\mathrm{TM}}$ used in the present study presents a higher degree of hydrolysis (1900 $\mathrm{Da})$.

The deleterious effect of the added SBTI was clearly demonstrated: mass and TRY activity were lower at day 15 and 30 in group I for which mean survival was the lowest (45\%) of all experimental group. Fish in this group were probably in very bad condition by having a restricted access to appropriate amount of amino acids, normally obtained via trypsin breakdown of whole proteins. In this group, digestive capacities were hampered by the presence of SBTI and contrarily to group HI, access to amino acids was not insured by the supply of pre-digested proteins.

We foresaw some level of compensatory effect of PH when administered in combination with a trypsin inhibitor in the diet which would in the best of cases, display growth rates equivalent (or similar) to the control group. Unexpectedly, a highly significant positive impact of the 
observed after 60 days: survival and mass of group HI were around 25\% higher and 20\%

291 higher than that of the control group. Adding only protein hydrolysate to the diet (group H) enhanced survival almost as much as group HI but did not enhance final fish mass. Even if it is well know that $\mathrm{PH}$ is not beneficial to juveniles, we were expecting the group $\mathrm{H}$ to perform better than HI since their digestive capacities were not hampered by an inhibitor. Different processes that might help to explain those results are discussed below.

Sveier et al. (2001) working on Atlantic salmon achieved best growth rates when both protease inhibitor and protein hydrolysate were added to the diet. They suggested that the changes in digestion and absorption patterns caused by the inhibitor might result in an extended digestion time and better protein utilization for growth.

Pre-digested proteins are more readily absorbed than intact proteins and result in a high postprandial peak of amino acids in the plasma (Espe et al., 1993, 1999). Carvalho et al.(2004) suggested that dietary excess of di- and tri-peptides was linked to reduced earlystage performance in common carp (Cyprinus carpio) either due to saturation of the peptide transport mechanisms and/or to the rapid hydrolysis of low-molecular weight peptides, that produced an excessive amino acid load, that in turn saturated the amino acid intestinal transport mechanisms.

In adult fish and in mammals, cholecystokinin (CCK) plays a major role in the pancreatic enzyme secretion (Singer, 1993). This gastro-intestinal hormone is secreted in response to the presence of nutrients in the lumen (Liddle, 1997) and stimulates trypsin and chymotrypsin secretion (Einarsson et al., 1997). On the other hand, trypsin acts with a feedback signal by degrading the CCK releasing factor and terminating CCK secretion (Herzig, 1998; Liddle, 2000; Cahu et al., 2004). In fact, food (proteins) act as a substrate for trypsin, bind it and prevent degradation of CCK releasing factor. In this particular case, trypsin was inactivated by SBTI and did not give the signal to stop pancreatic secretion. Growth could then be enhanced via an overcompensation of digestive enzyme secretion. This would imply that other digestive enzymes than trypsin would set digestive capacity and growth at these young stages (Rungruangsak-Torrissen, 2006). 
overcompensation of chymotrypsin secretion was not expressed in this group. In the case of TRY this overcompensation seemed to allow a steady state of the activity level despite the presence of the inhibitor. These results suggest that the improved performances of the groups provided with trypsin inhibitor and protein hydrolysate partly depend on overcompensation which is induced only when supplemented with small peptides. In a recent study Lilleeng et al. (2007) reported an upregulation of trypsin-like activity in the distal intestine wall. This increased activity may contribute to higher trypsin activity in the intestinal content and partly explain improved growth preformance when $\mathrm{PH}$ is supplemented in presence of trypsin inhibitor. This hypothesis could be also validated via the quantification of trypsin and chymotrypsin messenger RNA because enzyme activities do not necessarily equal their synthesis rate. In the case of trypsin and chymotrypsin, these are secreted in the form of inactive zymogens: respectively trypsinogen and chymotrypsinogen. These have to be activated by enterokinase or by their own active form. Consequently, if the enzymes are produced but readily inactivated by SBTI, their normal "self-activation" could be impaired resulting in a large quantity of zymogens but no measurable activity.

The PH used in our experiment was processed by enzymatic hydrolysis with endopeptidase (Seanergy inc. technical information on $\mathrm{HPC}^{\mathrm{TM}}$ ). Endogenous exoproteases (which nonspecifically cuts terminal amino acids from the peptide chain) may therefore play a more important role in the final digestion of PH than trypsin which is an endopeptidase. SBTI may extend the life of these exoproteases in the gut by blocking their digestion by trypsin thus increasing their net activity. Completion of the final steps of peptide digestion could then be facilitated and scope for growth of fish enhanced (Ross, N. Pers. Comm..). This hypothesis could be tested by estimating synthesis and expression of this exopeptidase under the same conditions used in the present study.

\section{Acknowledgement}

The authors would like to express their gratitude to Tony Grenier and Dany Ouellet for their technical assistance throughout the experiment. We are grateful to Dr. Neil Ross (CNRCPARI, Halifax, NS, Canada) for his constructive comments on an earlier version of the manuscript. The financial support of MAPAQ and Université du Québec à Rimouski to NLF is also acknowledged. 


\section{References}

Atlantic Wolffish Biological Review Team., 2009. Status review of Atlantic wolffish (Anarhichas lupus). Report to National Marine Fisheries Service, Northeast Regional Office. September 30, 2009. 149 pp.

Beaulieu, L., Thibodeau, J., Bryl, P., Carbonneau, M.-E., 2009. Proteolytic processing of Atlantic mackerel (Scomber scombrus) and biochemical characterization of hydrolysates. Int. J. Food Sci. Tech. 44, 1609-1618.

Blier, P., Pelletier, D., Dutil, J.-D., 1997. Does aerobic capacity set a limit on fish growth rate? Rev. Fish. Sci. 5, 323-340.

Cahu, C.L., Zambonino-Infante, J.L., 1995. Maturation of the pancreatic and intestinal digestive functions in sea bass (Dicentrarchus labrax) effect of weaning with different protein sources. Fish Physiol. Biochem. 14, 431-437.

Cahu, C.L., Zambonino Infante, J.L., Quazuguel, P., Le Gall, M.M., 1999. Protein hydrolysate vs. fish meal in compound diets for 10-day old sea bass Dicentrarchus labrax larvae. Aquaculture 171, 109-119.

Carvalho, A.P., Escaffre, A.-M., Oliva Teles, A., Bergot, P., 1997. First feeding of common carp larvae on diets with high levels of protein hydrolysates. Aquac. Int. 5, 361-367.

Cahu, C., Ronnestad, I., Grangier, V., Zambonino-Infante, J.L., 2004. Expression and activities of pancreatic enzymes in developing sea bass larvae (Dicentrarchus labrax) in relation to intact and hydrolyzed dietary protein; involvement of cholecystokinin. Aquaculture 238 (1-4), 295-308.

Carvalho, A.P., Sa, R., Oliva-Teles, A., Bergot, P., 2004. Solubility and peptide profile affect the utilization of dietary protein by common carp (Cyprinus carpio) during early larval stages. Aquaculture 234, 319-333.

Copp, G.H., Kovac, V. (1996) When do fish with indirect development become juveniles? Can. J. Fish. Aquat. Sci. 53: 746-752.

Delmar, E.G., Largman, C., Brodrick, J.W., Geokas, M.C., 1979. A sensitive new substrate for chymotrypsin. Anal. Biochem. 99, 316-320.

Desrosiers, V., Le François, N. R., \& Blier, P. U., 2008. Trypsin-like enzyme from atlantic wolffish (Anarhichas lupus) viscera: purification and characterization. J. Aquat. Food Prod. Technol., 17(1), 11-26.

Einarsson, S., Davies, P.S., Talbot, C., 1997. Effect of exogenous cholecystokinin on the discharge of the gallbladder and the secretion of trypsin and chymotrypsin from the pancreas of the Atlantic salmon, Salmo salar L. Comp. Biochem. Physiol. 117C, 63-67.

Erlanger, B.F., Kokowsky, N., Cohen, W., 1961. The preparation and properties of two new chromogenic substrates of trypsin. Arch. .Biochem. Biophys. 95, 271-278. 
Espe, M., Lied, E., Torrissen, K.R., 1993. Changes in plasma and muscle free amino acids in Atlantic salmon (Salmo salar) during absorption of diets containing different amounts of hydrolysed cod muscle protein. Comp. Biochem. Physiol. 105A, 555-562.

Espe, M., Sveier, H., Hogoy, I., Lied, E., 1999. Nutrient absorption and growth of Atlantic salmon (Salmo salar L.) fed fish protein concentrate. Aquaculture 174, 119-137.

397

398

399

400

401

402

403

404

405

406

407

408

409

410

411

412

413

414

415

416

417

418

419

420

421

422

423

424

425

426

427

428

Falk-Petersen, I.B., Hansen, T.K., 2001. Organ differentiation in newly hatched common wolfish. J. Fish Biol. 59(6), 1465-1482.

Flegler-Balon, C. 1989. Direct and indirect development in fishes: examples of alternative life-history styles. In: Bruton, M.N. (ed.) Alternative life-history styles of animals. Kluwer Academic Publishers, Dordrecht, the Netherlands, pp. 71-100.

Foss, A., Imsland, A.K., Falk-Petersen, I.B., Oiestad, V., 2004. A review of the culture potential of spotted wolffish Anarhichas minor Olafsen. Rev. Fish Biol. Fish. 14, 277-294.

Gisbert, E., Williot, P., 2002. Advances in the larval rearing of Siberian sturgeon. J. Fish Biol. 60(5), 1071-1092.

Govoni, J.J., Boehlert, G.W., Watanabe, Y., 1986. The physiology of digestion in fish larvae. Environ. Biol. Fishes 16, 59-77.

Herzig, K.H., 1998. Cholecystokinin and secretin releasing peptides in the intestine a new regulatory interendocrine mechanism in the gastrointestinal tract. Regul. Pept. 73, 89-94.

Imsland, A.K., Jonassen, T.M., 2003. Growth and age at first maturity in turbot and halibut reared under different photoperiods Aquac. Int. 11(5), 463-475.

Imsland, A.K. and Jonassen, T.M., 2005. The relation between age at first maturity and growth in Atlantic halibut (Hippoglossus hippoglossus) reared at four different light regimes Aquac. Res. 36(1), 1-7.

Imsland, A.K., Foss, A., Koedijk, R., Folkvord, A., Stefansson, S.O., Jonassen, T.M., 2007. Persistent growth effects of temperature and photoperiod in Atlantic cod Gadus morhua. J. Fish Biol. 71(5), 1371-1382.

Kolkovski, S., 2001. Digestive enzymes in fish larvae and juveniles implications and applications to formulated diets. Aquaculture 200, 181-201.

Kotzamanis, Y. P., Gisbert, E., Gatesoupe, F. J., Zambonino-Infante, J., Cahu, C., 2007. Effects of different dietary levels of fish protein hydrolysates on growth, digestive enzymes, gut microbiota, and resistance to Vibrio anguillarum in European sea bass (Dicentrarchus labrax) larvae. Comp. Bioch. Physiol. A 147(1), 205-214.

Krogdahl, A., Lea, T.B., Olli, J.J., 1994. Soybean proteinase inhibitors affect intestinal trypsin activities and amino acid digestibilities in rainbow trout (Oncorhynchus mykiss). Comp. Biochem. Physiol. A 107 (1), 215-219.

Kulka, D., Hood, C., Huntington, J., 2007. Recovery strategy for Northern wolffish (Anarhichas denticulatus) and spotted wolffish (A. minor), and management plan for Atlantic wolffish (A. 
lupus) in Canada. Fisheries and Oceans Canada: Newfoundland and Labrador region. St.John's, NL. $x+103$ pp.

Kvale, A., Harboe, T., Mangor-Jensen, A., Hamre, K., 2009. Effects of protein hydrolysate in weaning diets for Atlantic cod (Gadus morhua L.) and Atlantic halibut (Hippoglossus hippoglossus L.). Aquacult. Nutr. 15(2), 218-227.

Lamarre, S.G., Blier, P.U., Driedzic, W.R., Le François, N.R. (2010) White muscle 20S proteasome

435

436

437

438

439

440

441

442

443

444

445

446

447

448

449

450

451

452

453

454

455

456

457

458

459

460

461

462

463

464

465 activity is negatively correlated to growth rate at low temperature in the spotted wolffish Anarhichas minor. J. Fish. Biol. 76 (7), 1565-1575.

Lamarre, S.G., Le Francois, N.R., Falk-Petersen, I.-B., Blier, P.U., 2004. Can digestive and metabolic enzyme activity levels predict growth rate and survival of newly hatched Atlantic wolffish (Anarhichas lupus)? Aquac. Res. 35, 608-613.

Lamarre, S.G., Le François, N.R., Lemieux, H., Falk-Petersen, I.-B., Blier, P.U., 2007. The digestive and metabolic enzyme activity profiles of a nonmetamorphic marine fish species : effects of feed type and feeding level. Can. J. Fish Aquat. Sci. 64, 849-856.

Le François, N.R., Lemieux, H., Blier, P.U., 2002. Biological and technical evaluation of the potential of marine and anadromous fish species for cold-water mariculture. Aquac. Res. 33, 95-108.

Le François, N.R., Tveiten, H., Halfyard, L.C., Foss, A. The Wolffishes (Family : Anarhichadidae). p. 417-431 in: Finfish Aquaculture Diversification (N.R. Le François, M. Jobling, C. Carter and P.U. Blier, eds). CAB International, 681 pp.

Lemieux, H., Blier, P. U. 2007. Trypsin activity measurement in fish and mammals: Comparison of four different methods. J. Aquat. Food Prod. Technol., 16(4), 13-26.

Lemieux, H., Blier, P.U., Dutil, J.D., 1999. Do digestive enzymes set a physiological limit on growth rate and food conversion efficiency in the Atlantic cod (Gadus morhua)? Fish Physiol. Biochem. 20(4), 293-303.

Liddle, R.A., 1997. Cholecystokinin cells. Annu. Rev. Physiol. 59, 221- 242.

Liddle, R.A., 2000. Regulation of cholecystokinin secretion in humans, J. Gasteroenterol. 35, 181187.

Liddle, R.A., Goldfine, I.D.,Williams, J.A., 1984. Bioassay of plasma cholecystokinin in rats: effects of food, trypsin inhibitor, and alcohol. Gastroenterology 87, 542-549.

Lilleeng, E., Froystad, M. K., Ostby, G. C., Valen, E. C., \& Krogdahl, A. 2007. Effects of diets containing soybean meal on trypsin mRNA expression and activity in Atlantic salmon (Salmo salar L). Comp. Biochem. Physiol. - A Molecular and Integrative Physiology, 147(1), 25-36.

Morton, K., Schwartz, (1971) Clinical aspects of aspartate and alanine aminotransferases, Methods in Enzymology, Volume 17, Part 2, 1971, pp. 866-875..

Nankervis, L., Southgate, P., 2009. Enzyme and acid treatment of fish meal for incorporation into formulated microbound diets for barramundi (Lates calcarifer) larvae. Aquacult. Nutr. 15(2), 135143. 
Oliva-Teles, A., Cerqueira, A.L., Goncalves, P., 1999. The utilization of diets containing high levels of fish protein hydrolysate by turbot (Scophthalmus maximus) juveniles. Aquaculture 179 (1-4), 195-201.

Olli, J.J., Hjelmeland, K., Krogdahl, A., 1004. Soybean trypsin-inhibitors in diets for Atlantic salmon (Salmo salar L.) - Effects on nutrient digestibilities and trypsin in pyloric ceca homogenate and intestinal content. Comp. Bioch. Physiol. 109(4), 923-928.

Paine, M.D., Balon, E.K. 1984. Early development of the rainbow darter, Etheostoma caeruleum, according to the theory of saltatory ontogeny. Environ. Biol. Fishes 11, 277-299.

Roennestad, I., Rojas-Garcia, C.R., Tonheim, S.K., Conceicao, L.E.C., 2001. In vivo studies of digestion and nutrient assimilation in marine fish larvae. Aquaculture 201, 161-175.

Rungruangsak-Torrissen, K., Moss, R., Andresen, L. H., Berg, A., \& Waagbø, R. (2006). Different expressions of trypsin and chymotrypsin in relation to growth in Atlantic salmon (Salmo salar L.). Fish Physiol. Biochem., 32(1), 7-23.

Rust, M.B., 1995. Quantitative aspects of nutrient assimilation in six species of fish larvae. Ph.D. Thesis, School of Fisheries, University of Washington, Seattle.

Sala R., Santamaria, C.A., Crespo, S., 2005. Growth of organ systems of Dentex dentex (L.) and Psetta maxima (L.) during larval development. J. Fish Biol. 66, 315-326.

Savoie, A., Le François, N.R., Cahu, C., Blier, P.U., Andreassen, I., 2006. Do protein hydrolysates improve survival and growth of newly-hatched spotted wolffish (Anarhichas minor), a nonmetamorphic aquaculture fish species? Aquaculture 261(2), 782-788.

Savoie, A., Le François, N.R., Cahu, C.L., Andreassen, I. and Blier, P.U., 2008. Metabolic and digestive enzyme activity profiles of newly-hatched spotted wolffish (Anarhichas minor Olafsen): effect of temperature. Aquac. Res. 39(4), 382-389.

Schwartz, M.K., 1971. Clinical aspects of aspartate and alanine aminotransferases, Meth. Enzymol. 17(2), 866-875.

Sharma, J.G., Chakrabarti, R., 1999. Larval rearing of common carp Cyprinus carpio: a comparison between natural and artificial diets under three stocking densities. J. World Aquac. Soc. 30(4), 490-495.

Silk, D.B.A., Grimble, G.K., Rees, R.G., 1985. Protein digestion and amino acid and peptide absorption. Proc. Nutr. Soc. 44, 63-72.

Singer, M., 1993. Neurohormonal control of pancreatic enzyme secretion in animals. In: Go, V.L.W., Gardner, J.D., Brooks, F.P., Lebenthal, E., DiMagno, E.P., Sheele, G.A. (Eds.), The Pancreas: Biology, Pathobiology, and Disease, 2nd ed. Raven Press, New York, pp. 425- 448.

Smith P.K., Krohn, R.I.., Hermanson, G.T., Mallia, A.K., Gartner, F.H., Provenzano, M.D., Fujimoto, E.K., Goeke, N.M., Olson, B.J., Klenk, D.C., 1985. Measurement of protein using bicinchoninic acid. Anal. Biochem. 150, 76-85. 
Sveier, H., Kvamme, B.O., Raae, A.J., 2001. Growth and protein utilization in Atlantic salmon (Salmo salar L.) given a protease inhibitor in the diet. Aq. Nut. 7(4), 255-264.

504 Szlaminska, M., Escaffre, A.M., Charlon, N., Bergot, P., 1993. Preliminary data on semisynthetic diet 505 for goldfish (Carassius auratus L.) larvae. In: Kaushik, S.J., Luquet, P. (Eds.), Fish Nutrition in 506 Practice. INRA, Paris, pp. 606-612.

507 Zambonino-Infante, J.L., Cahu, C.L., Peres, A., 1997. Partial substitution of di- and tripeptides for 508 native proteins in sea bass diet improves Dicentrarchus labrax larval development. J. Nut. 127(4), 509 608-614.

510 Zambonino-Infante, J.L., Cahu, C.L., 2001. Ontogeny of the gastrointestinal tract of marine fish 511 larvae. Comp. Biochem. Physiol., 130C, 477-487.

512

\section{Figure captions}

514 Figure 1 Molecular weight distribution of the HPC90 shrimp protein hydrolysate (Ocean 515 NutraScience Inc., Matane (QC), Canada) determined by gel permeation chromatography 516

517 Figure 2 Survival (\%) and productivity (g/tank, mean weight * survival) of spotted wolfish at 518 the end of the experiment (60 DPH).

520 Figure 3 Mean weight of spotted wolfish according to diet (C, H, HI, I) and days post521 hatching

523 Figure 4 Enzymatic activities of aspartate aminotransferase (AST), chymotrypsin (CHY) and 524 trypsin (TRY) of entire larvae of spotted wolffish according to diet (C, H, HI, I) and days 525 post-hatching 


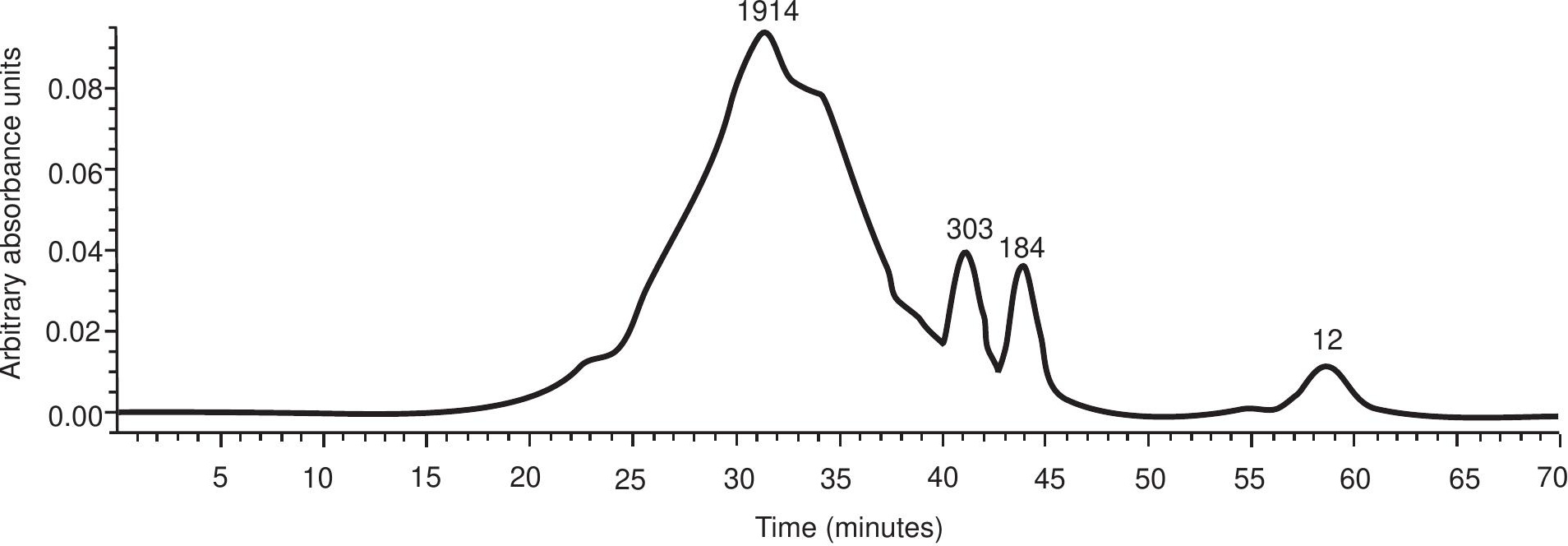




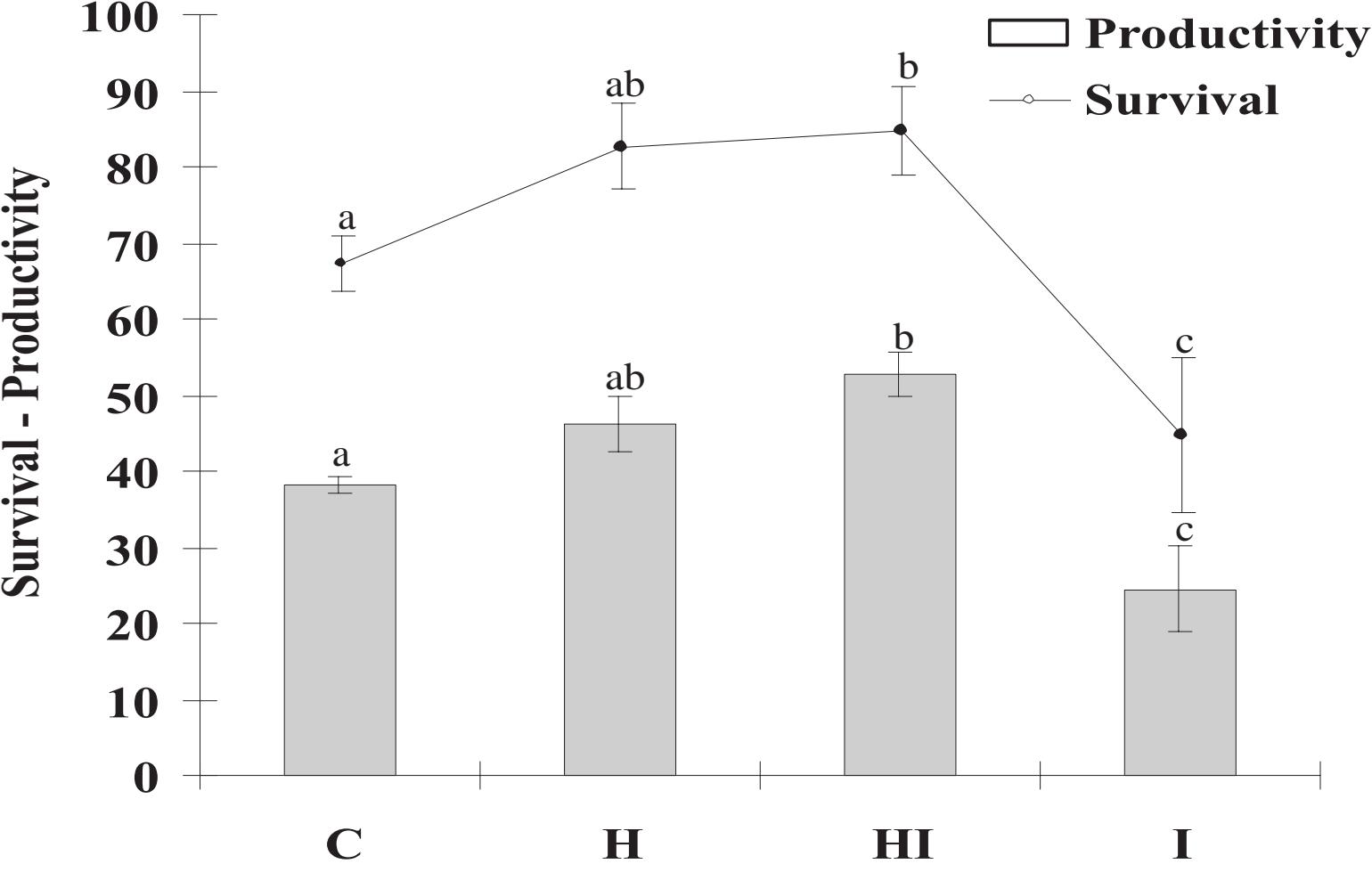

Diet 


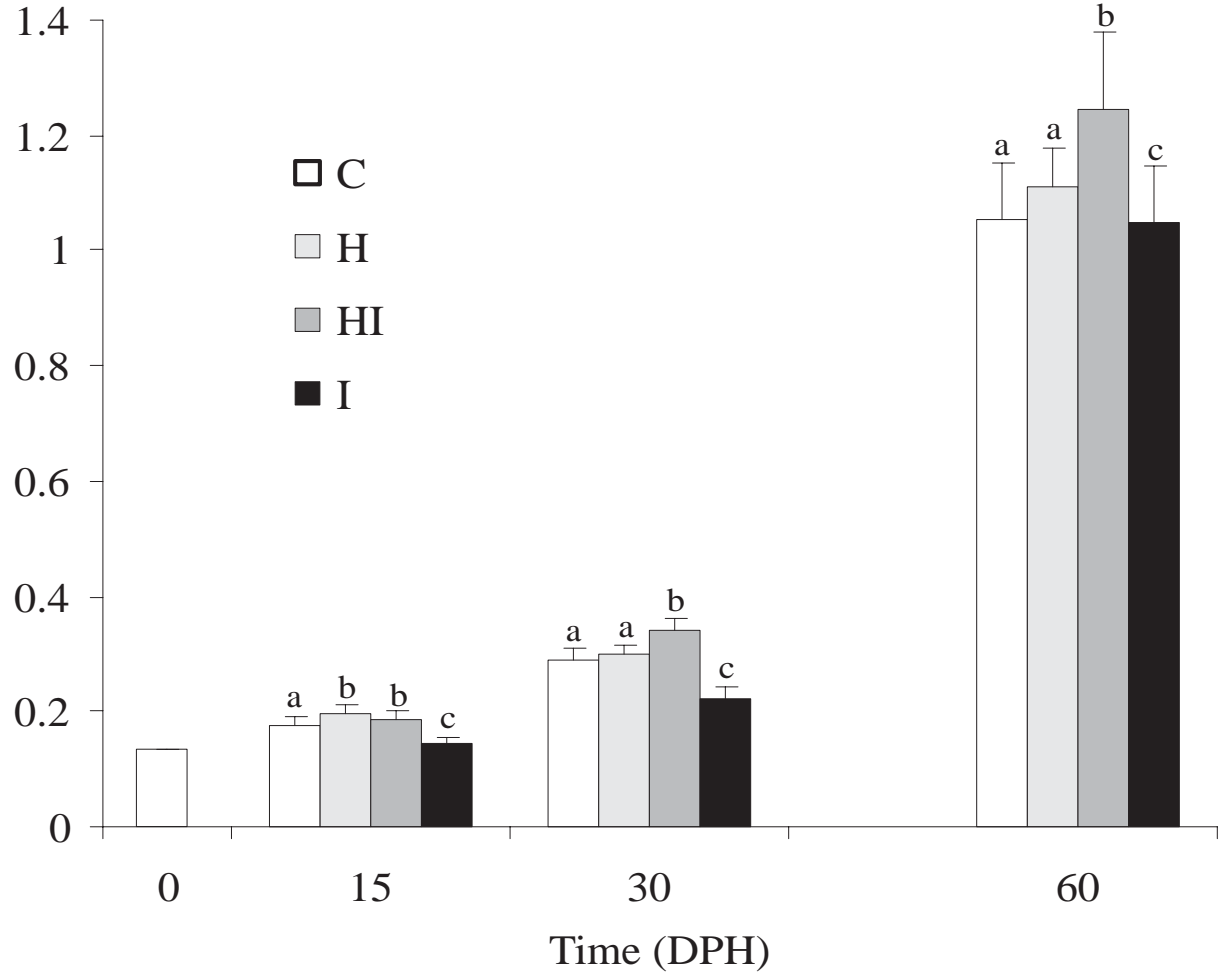



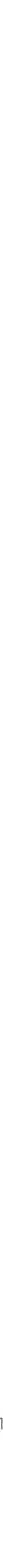